\title{
Microwave plaque thermoradiotherapy for choroidal melanoma
}

\author{
Paul T Finger
}

\begin{abstract}
Microwave thermoradiotherapy was used as a primary treatment for 44 patients with choroidal melanoma. An episcleral dishshaped microwave antenna was placed beneath the tumour at the time of plaque brachytherapy. While temperatures were measured at the sclera, the tumour's apex was targeted to receive a minimum of $42^{\circ} \mathrm{C}$ for 45 minutes. In addition, the patients received full or reduced doses of plaque radiotherapy. No patients have been lost to follow-up. Two eyes have been enucleated: one for rubeotic glaucoma, and one for uveitic glaucoma. Though six patients have died, only one death was due to metastatic choroidal melanoma (39 months after treatment). Clinical observations suggest that the addition of microwave heating to plaque radiation therapy of choroidal melanoma has been well tolerated. There has been a $\mathbf{9 7 . 7 \%}$ local control rate (with a mean follow-up of 22.2 months). We have reduced the minimum tumour radiation dose (apex dose) to levels used for thermoradiotherapy of cutaneous melanomas $(50 \mathrm{~Gy} / 5000 \mathrm{rad})$. Within the range of this follow-up period no adverse effects which might preclude the use of this microwave heat delivery system for treatment of choroidal melanoma have been noted.
\end{abstract}

Heat has been shown to potentiate radiation in the treatment of cancer. ${ }^{1-6}$ This is because hyperthermia can directly kill cells, it can inactivate cellular enzymes (for example, those used to repair radiation damage), and high level heating can damage blood vessels. ${ }^{7-13}$ While all tissues are primarily cooled by blood flow, neoplastic tissues are particularly heat sensitive. This is thought to be because they have poorly developed vascular systems which are often redundant and inefficient, leading to poor perfusion, necrosis, acidosis, and hypoxia.$^{1+18}$ When heat is delivered to a cancer, the poorly perfused (radiation resistant) areas concentrate heat and are preferentially damaged. ${ }^{17} 18$

For effective clinical hyperthermia it is necessary that heat delivery systems be tailored to account for the blood flow and location of the tumour. Ideal heat distributions target the neoplasm and/or its vascular supply with relative sparing of normal tissues. Choroidal melanomas seem uniquely vulnerable to microwave thermotherapy. These are comparatively small tumours which project into the avascular vitreous and are therefore largely dependent on basal blood vessels emanating from the choroid. Episcleral application of a microwave plaque targets the base of an intraocular tumour and preferentially heats its vascular supply. ${ }^{19-21}$ The only normal structures to receive high dose thermotherapy are the relatively heat resistant sclera and cornea directly beneath the episcleral plaque. ${ }^{22} 23$

In this series microwave thermotherapy was used in conjunction with plaque radiotherapy for treatment of 44 patients with choroidal melanoma. Encouraged by early reductions of tumour height, we reduced the minimum tumour radiation dose (tumour apex) to levels used in treatment of cutaneous melanomas. ${ }^{1-3}$ The associated reductions in radiation to normal ocular structures should decrease the incidence of radiation-associated complications.

This report includes a description of microwave plaque construction, the technique of treatment, microwave and radiation dosimetry, and clinical observations.

\section{Materials and methods}

All patients in this series were diagnosed as having choroidal melanoma by clinical examination. Since the time we joined the Collaborative Ocular Melanoma Study (COMS) all eligible patients were told of two standard methods of treatment available to them through participation in the COMS..$^{24}$ Ineligible patients and those who refused to join the study were offered observation, enucleation, radiation, or radiation with microwave hyperthermia. This involved a detailed discussion of the risks and benefits of each therapeutic form as it related to their tumour's size, location, and risk of metastasis.

Hospital Internal Review Board (IRB) approvals and a United States of America, Food and Drug Administration investigational device exemption (IDE) were obtained prior to this clinical study. All patients were informed of the investigative nature of microwave thermotherapy. They were told of how many patients had been treated, how long they had been followed-up for complications or recurrence, and the significance of those facts. The mechanism of action of adjuvant heat therapy in other tumour systems, and the rationale for reducing the amount of ionising radiation delivered to the tumour's apex were also explained as well as possible. ${ }^{1-3}$ Though no significant scleral damage has been noted in this series, the possibility of such damage (as noted in preclinical studies) was discussed. ${ }^{20}$

The patients had a complete eye examination prior to treatment. After refraction, pupillary, ocular motor, and slit-lamp examinations were performed. Goldmann tonometry was used to measure intraocular pressure. Ophthalmoscopy was performed with direct, indirect and contact lens techniques as applicable. Standardised echography was performed. ${ }^{25} \mathrm{~A}$-scan was used to measure tumour height and evaluate internal

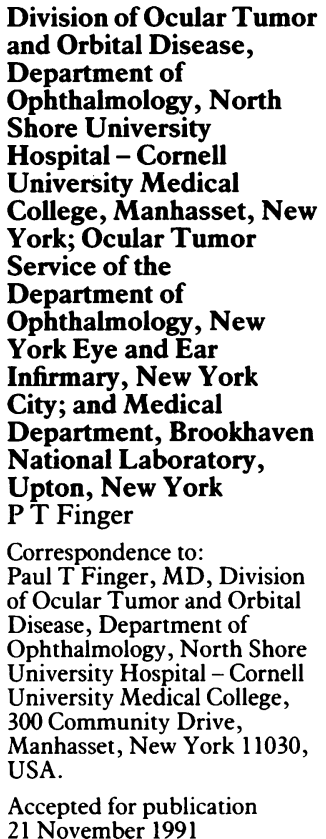


reflectivity. B-scan echography was used to determine tumour location, shape, associated retinal detachments, and to evaluate choroidal excavation or extrascleral tumour extension. Fluorescein angiography, slit-lamp, and fundus photography were performed when possible.

All tumours in this series had base diameters greater than $10 \mathrm{~mm}$ or heights greater than or equal to $3 \mathrm{~mm}$. Six patients had large melanomas as defined by a tumour height greater than $8 \mathrm{~mm}$, and 38 had medium sized tumours with heights greater than or equal to $3 \mathrm{~mm}$. No patients with a tumour basal diameter of greater than $16 \mathrm{~mm}$ were treated. Three patients had ciliary body melanomas, and three juxtapapillary tumours were contiguous with the optic nerve (Table 1).

Preoperative investigations for metastases were performed on all patients. They included a physical examination, blood tests (sequential multiple analyser profile (SMA-12), gammaglutamyl transpeptidase (GGT), complete blood count (CBC)), and a chest $x$ ray. Computed axial tomography of the orbits was performed if extraocular extension was suspected on ultrasonography. Computed tomography of the abdomen was performed for increased liver enzymes or at the patient's request.

In most cases the patients were examined after surgery, at 24 hours, 7 days, 1 month, 3 months, then every 3 months for 2 years, and finally at 6month intervals. Examinations included tests of visual acuity, pupillary function, ocular motor function, a slit-lamp examination, intraocular pressure measurements, and ophthalmoscopy. Ultrasonography, fundus photography, and fluorescein angiography were also used to evaluate tumour response and ocular health. Systemic examinations were performed approximately each year after treatment. These included a physical examination, repeat haematological studies, and chest $x$ ray.

\section{MICROWAVE THERMOTHERAPY}

\section{Plaque construction}

Microwave plaques were constructed by MMTC Corp (Princeton, NJ, USA), and thermocouple assemblies were added at Brookhaven National Laboratory (Upton, NY, USA). The resonant portion of the disc-shaped antenna was constructed by photoetching a copper disc on the surface of a Teflon fibreglass dielectric substrate (RT-Duroid 5880, Rogers Corp, Chandler, AZ, USA). The etching process selectively left a $2 \mathrm{~mm}$ free margin between the copper disc and the edge of the antenna (Fig 1). ${ }^{2026}$

A short length of flexible silicone-covered coaxial cable AS 450-3650 SR (Cooner Wire, Chatsworth, CA, USA) was used to direct the microwave energy from the microwave generator/ amplifier to the patch antenna. The silicone coating was removed at one end which exposed the centre conductor. To form an electrical return, the outer mesh was soldered to the copper backing of the duroid substrate. Then the

Table 1 Patient data: tumour size, location, and shape

\begin{tabular}{|c|c|c|c|c|c|c|c|c|c|c|}
\hline Number & Surgery & Length & Width & Height & Eye & Clock $h$ & Apex Loc. & $m m$ to $O N$ & $m m$ to $F$ & Shape \\
\hline $\begin{array}{r}1 \\
2 \\
3 \\
4 \\
5 \\
6 \\
7 \\
8 \\
9 \\
10\end{array}$ & $\begin{array}{l}\text { Jul-86 } \\
\text { Aug-86 } \\
\text { Oct-86 } \\
\text { Jan-87 } \\
\text { Mar-87 } \\
\text { May-87 } \\
\text { Jun-87 } \\
\text { Jul-87 } \\
\text { Aug-87 } \\
\text { Oct-87 }\end{array}$ & $\begin{array}{r}15 \\
7 \\
9 \\
16 \\
12 \\
15 \\
8 \\
6 \\
8 \\
14\end{array}$ & $\begin{array}{r}15 \\
10 \\
7 \\
16 \\
8 \\
15 \\
6 \\
5 \\
8 \\
12\end{array}$ & $\begin{array}{c}3 \\
3 \\
3 \cdot 5 \\
12 \cdot 2 \\
4 \\
10 \\
3 \\
4 \cdot 7 \\
3 \cdot 7 \\
8 \cdot 4\end{array}$ & $\begin{array}{l}\text { Right } \\
\text { Right } \\
\text { Left } \\
\text { Right } \\
\text { Left } \\
\text { Right } \\
\text { Right } \\
\text { Left } \\
\text { Left } \\
\text { Left }\end{array}$ & $\begin{array}{r}3: 00 \\
6: 00 \\
8: 00 \\
4: 00 \\
5: 30 \\
10: 00 \\
7: 30 \\
1: 30 \\
4: 30 \\
4: 00\end{array}$ & $\begin{array}{l}\text { EP } \\
\text { EA } \\
\text { EP } \\
\text { E } \\
\text { E } \\
\text { E } \\
\text { EA } \\
\text { PE } \\
\text { PE } \\
\text { E }\end{array}$ & $\begin{array}{l}3 \cdot 4 \\
7 \\
8 \\
7 \\
6 \cdot 2 \\
10 \\
16 \\
1 \cdot 5 \\
3 \\
10\end{array}$ & $\begin{array}{c}0 \\
8 \\
11 \\
10 \cdot 4 \\
6 \\
13 \cdot 4 \\
15 \cdot 6 \\
1.5 \\
4 \cdot 5 \\
12\end{array}$ & $\begin{array}{l}\text { Dome } \\
\text { Dome } \\
\text { Dome } \\
\text { Collar B } \\
\text { Dome } \\
\text { Collar B } \\
\text { Dome } \\
\text { Collar B } \\
\text { Dome } \\
\text { Collar B }\end{array}$ \\
\hline $\begin{array}{l}11 \\
12 \\
13 \\
14 \\
15 \\
16 \\
17 \\
18 \\
19 \\
20 \\
21 \\
22 \\
23 \\
24 \\
25 \\
26 \\
27 \\
28 \\
29 \\
30 \\
31 \\
32 \\
33 \\
34 \\
35 \\
36 \\
37 \\
38 \\
39\end{array}$ & $\begin{array}{l}\text { Oct-87 } \\
\text { Nov-87 } \\
\text { Feb-88 } \\
\text { Apr-88 } \\
\text { Sep-88 } \\
\text { Nov-88 } \\
\text { Dec-88 } \\
\text { Jan-89 } \\
\text { Feb-89 } \\
\text { Apr-89 } \\
\text { Jun-89 } \\
\text { Jul-89 } \\
\text { Jul-89 } \\
\text { Jul-89 } \\
\text { Sep-89 } \\
\text { Oct-89 } \\
\text { Nov-89 } \\
\text { Nov-89 } \\
\text { Nov-89 } \\
\text { Jan-90 } \\
\text { Feb-90 } \\
\text { Feb-90 } \\
\text { Feb-90 } \\
\text { Mar-90 } \\
\text { May-90 } \\
\text { Jun-90 } \\
\text { Jun-90 } \\
\text { Jul-90 } \\
\text { Aug-90 }\end{array}$ & $\begin{array}{l}15 \\
10 \\
12 \\
10 \\
8 \\
15 \\
7 \cdot 5 \\
14 \\
11 \\
15 \\
12 \\
9 \\
9 \\
10 \\
8 \\
10 \\
6 \\
10 \\
10 \\
8 \\
10 \\
10 \\
10 \\
10 \\
9 \\
11 \\
7 \\
9 \\
12\end{array}$ & $\begin{array}{c}14 \\
8 \\
12 \\
8 \\
8 \\
15 \\
5 \cdot 5 \\
12 \\
11 \\
12 \\
12 \\
9 \\
8 \\
8 \\
6 \\
10 \\
5 \\
10 \\
10 \\
6 \\
9 \\
10 \\
9 \\
10 \\
7 \\
10 \\
7 \\
7 \\
12\end{array}$ & $\begin{array}{l}4 \cdot 4 \\
3 \cdot 9 \\
5 \cdot 7 \\
3 \cdot 7 \\
3 \cdot 2 \\
3 \cdot 4 \\
3 \cdot 4 \\
3 \cdot 9 \\
6 \cdot 4 \\
5 \cdot 7 \\
7 \cdot 4 \\
3 \cdot 7 \\
8 \cdot 1 \\
5 \cdot 2 \\
3 \cdot 2 \\
5 \cdot 2 \\
3 \cdot 2 \\
5 \cdot 4 \\
3 \cdot 2 \\
5 \cdot 9 \\
5 \cdot 2 \\
6 \cdot 4 \\
3 \cdot 7 \\
6 \cdot 6 \\
4 \cdot 7 \\
8 \cdot 1 \\
3 \cdot 4 \\
3 \cdot 2 \\
5 \cdot 9\end{array}$ & $\begin{array}{l}\text { Left } \\
\text { Left } \\
\text { Right } \\
\text { Left } \\
\text { Left } \\
\text { Left } \\
\text { Right } \\
\text { Right } \\
\text { Right } \\
\text { Left } \\
\text { Right } \\
\text { Left } \\
\text { Right } \\
\text { Left } \\
\text { Left } \\
\text { Left } \\
\text { Left } \\
\text { Right } \\
\text { Right } \\
\text { Left } \\
\text { Left } \\
\text { Left } \\
\text { Right } \\
\text { Right } \\
\text { Right } \\
\text { Right } \\
\text { Left } \\
\text { Left } \\
\text { Right }\end{array}$ & $\begin{array}{r}3: 00 \\
5: 00 \\
6: 30 \\
10: 00 \\
9: 00 \\
7: 30 \\
10: 30 \\
9: 30 \\
12: 30 \\
2: 30 \\
8: 00 \\
3: 30 \\
4: 30 \\
3: 30 \\
5: 00 \\
10: 00 \\
3: 00 \\
3: 00 \\
8: 00 \\
4: 00 \\
8: 00 \\
2: 00 \\
3: 30 \\
10: 00 \\
8: 00 \\
5: 00 \\
7: 00 \\
2: 00 \\
3: 00\end{array}$ & $\begin{array}{l}\text { EA } \\
\text { EP } \\
\text { PE } \\
\text { EA } \\
\text { E } \\
\text { EP } \\
\text { EP } \\
\text { E } \\
\text { P } \\
\text { PE } \\
\text { EP } \\
\text { E } \\
\text { E } \\
\text { E } \\
P \\
P \\
P E \\
C B \\
P \\
P E \\
C B \\
P E \\
\text { E } \\
P E \\
P \\
\text { EP } \\
C B \\
\text { EP } \\
\text { EA }\end{array}$ & $\begin{array}{c}14 \\
6 \\
1 \\
11 \cdot 7 \\
4 \\
2 \\
7 \cdot 5 \\
11 \\
0 \\
3 \\
3 \cdot 5 \\
10 \\
4 \\
7 \\
0 \\
1 \cdot 5 \\
1 \cdot 5 \\
17 \\
0 \\
1 \\
17 \cdot 3 \\
3 \\
7 \cdot 5 \\
5 \\
1 \cdot 5 \\
1 \cdot 5 \\
17 \\
5 \cdot 4 \\
7\end{array}$ & $\begin{array}{c}10 \cdot 6 \\
5 \\
1 \cdot 5 \\
12 \cdot 2 \\
7 \\
7 \cdot 5 \\
5 \\
7 \cdot 5 \\
0 \\
0 \\
1 \\
6 \\
7 \cdot 5 \\
3 \cdot 5 \\
0 \\
4 \cdot 5 \\
0 \\
19 \cdot 3 \\
0 \\
0 \\
19 \cdot 6 \\
1 \cdot 5 \\
10 \cdot 5 \\
2 \\
0 \\
1 \cdot 5 \\
19 \cdot 5 \\
2 \\
10 \cdot 4\end{array}$ & $\begin{array}{l}\text { Dome } \\
\text { Dome } \\
\text { Dome } \\
\text { Dome } \\
\text { Dome } \\
\text { Dome } \\
\text { Dome } \\
\text { Dome } \\
\text { Collar B } \\
\text { Dome } \\
\text { Dome } \\
\text { Dome } \\
\text { Collar B } \\
\text { Dome } \\
\text { Dome } \\
\text { Dome } \\
\text { Collar B } \\
\text { Dome } \\
\text { Dome } \\
\text { Dome } \\
\text { Dome } \\
\text { Dome } \\
\text { Dome } \\
\text { Collar B } \\
\text { Dome } \\
\text { Collar B } \\
\text { Dome } \\
\text { Dome } \\
\text { Dome }\end{array}$ \\
\hline $\begin{array}{l}40 \\
41 \\
42 \\
43 \\
44\end{array}$ & $\begin{array}{l}\text { Sept-90 } \\
\text { Sep-90 } \\
\text { Sep-90 } \\
\text { Oct-90 } \\
\text { Feb-91 }\end{array}$ & $\begin{array}{l}10 \\
16 \\
10 \\
12 \\
10\end{array}$ & $\begin{array}{l}10 \\
16 \\
10 \\
10 \\
10\end{array}$ & $\begin{array}{l}3 \cdot 4 \\
5 \cdot 9 \\
4 \cdot 2 \\
8 \cdot 6 \\
3 \cdot 4\end{array}$ & $\begin{array}{l}\text { Right } \\
\text { Left } \\
\text { Left } \\
\text { Right } \\
\text { Right }\end{array}$ & $\begin{array}{r}8: 00 \\
3: 30 \\
2: 00 \\
9: 00 \\
10: 00\end{array}$ & $\begin{array}{l}\text { EP } \\
\text { EP } \\
\text { EP } \\
\text { E } \\
\text { EP }\end{array}$ & $\begin{array}{c}12 \\
3 \cdot 4 \\
3 \cdot 5 \\
11 \\
5\end{array}$ & $\begin{array}{l}8 \\
0 \\
1 \\
7 \cdot 4 \\
1 \cdot 5\end{array}$ & $\begin{array}{l}\text { Dome } \\
\text { Dome } \\
\text { Dome } \\
\text { Collar B } \\
\text { Dome }\end{array}$ \\
\hline
\end{tabular}

Ultrasonic apex locations: $\mathrm{P}=$ posterior; $\mathrm{PE}=$ posterior equator; $\mathrm{EP}=$ equator posterior; $\mathrm{E}=$ equator $\mathrm{EA}=$ equator anterior; $\mathrm{CB}=$ ciliary body. 
Figure 1 A plaque-shaped microwave antenna affixed plaque, a white miniature coaxial cable is noted leaving the plaque (arrow). The plaque is shown prior to thermocouple assembly and silicone insulation for better visualisation. within a gold episcleral

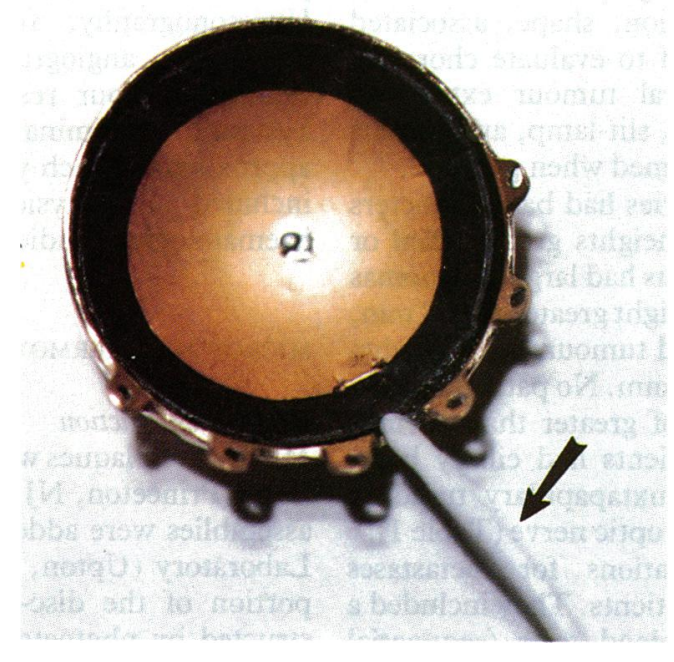

exposed centre conductor was placed through a central hole drilled in the disc-shaped antenna and soldered on to its anterior surface. Lastly a U-shaped wire was inserted through holes at the edge of the copper etched surface and soldered on the top and bottom surfaces to complete the circuit.

To monitor temperatures during treatment three copper-constantan thermocouples were affixed (cyanoacrylate to the anterior surface of the microwave antenna and bent $90^{\circ}$ to bring the thermocouple tips into contact with the sclera. The anterior surface of the microwave dish was insulated up to the tips of the thermocouples

Table 2 Methods

\begin{tabular}{|c|c|c|c|c|c|c|c|}
\hline Number & $\begin{array}{l}\text { Base dose } \\
(G y)\end{array}$ & $\begin{array}{l}6 \mathrm{~mm} \text { dose } \\
(G y)\end{array}$ & $\begin{array}{l}\text { Apex dose } \\
(G y)\end{array}$ & $\begin{array}{l}\text { Apex dose } \\
\text { (rate cGy/h) }\end{array}$ & $\begin{array}{l}\text { Temp } \\
\left({ }^{\circ} \mathrm{C}\right)\end{array}$ & $\begin{array}{l}\text { Time } \\
\text { (minutes) }\end{array}$ & $\begin{array}{l}F / U \\
\text { (months) }\end{array}$ \\
\hline $\begin{array}{r}1 \\
2 \\
3 \\
4 \\
5 \\
6 \\
7 \\
8 \\
9 \\
10\end{array}$ & $\begin{array}{l}195 \\
200 \\
211 \\
454 \\
219 \\
535 \\
124 \\
302 \\
236 \\
263\end{array}$ & $\begin{array}{r}59 \\
54 \\
62 \\
141 \\
66 \\
156 \\
37 \\
70 \\
45 \\
89\end{array}$ & $\begin{array}{l}88 \\
85 \\
88 \\
40 \\
80 \\
66 \\
58 \\
79 \\
63 \\
59\end{array}$ & $\begin{array}{r}68 \\
113 \\
125 \\
40 \\
110 \\
40 \\
110 \\
85 \\
118 \\
58\end{array}$ & $\begin{array}{l}47 \\
47 \\
48 \\
50 \\
50 \\
52 \cdot 5 \\
52 \\
50 \\
52 \\
49\end{array}$ & $\begin{array}{l}45 \\
45 \\
45 \\
45 \\
45 \\
45 \\
45 \\
45 \\
45 \\
45\end{array}$ & $\begin{array}{l}12 \\
52 \\
48 \\
55 \\
48 \\
29 \\
21 \\
36 \\
44 \\
46\end{array}$ \\
\hline $\begin{array}{l}11 \\
12 \\
13 \\
14 \\
15 \\
16 \\
17 \\
18 \\
19 \\
20 \\
21 \\
22 \\
23 \\
24 \\
25 \\
26 \\
27 \\
28 \\
29 \\
30 \\
31 \\
32 \\
33 \\
34 \\
35 \\
36 \\
37 \\
38 \\
39\end{array}$ & $\begin{array}{l}193 \\
132 \\
221 \\
143 \\
204 \\
111 \\
162 \\
130 \\
228 \\
164 \\
262 \\
175 \\
378 \\
228 \\
148 \\
215 \\
176 \\
200 \\
153 \\
257 \\
201 \\
292 \\
165 \\
296 \\
206 \\
290 \\
151 \\
124 \\
193\end{array}$ & $\begin{array}{l}59 \\
41 \\
67 \\
44 \\
43 \\
39 \\
34 \\
45 \\
66 \\
57 \\
81 \\
41 \\
95 \\
57 \\
30 \\
56 \\
27 \\
50 \\
39 \\
60 \\
47 \\
73 \\
42 \\
74 \\
52 \\
91 \\
34 \\
31 \\
60\end{array}$ & $\begin{array}{l}68 \\
52 \\
60 \\
59 \\
64 \\
50 \\
50 \\
53 \\
50 \\
49 \\
52 \\
56 \\
51 \\
55 \\
48 \\
52 \\
45 \\
48 \\
60 \\
50 \\
45 \\
55 \\
56 \\
53 \\
55 \\
50 \\
50 \\
48 \\
50\end{array}$ & $\begin{array}{r}98 \\
120 \\
89 \\
80 \\
95 \\
90 \\
140 \\
57 \\
68 \\
60 \\
80 \\
48 \\
37 \\
78 \\
93 \\
73 \\
58 \\
100 \\
88 \\
69 \\
62 \\
76 \\
116 \\
74 \\
70 \\
67 \\
70 \\
67 \\
70\end{array}$ & $\begin{array}{l}49 \cdot 3 \\
47 \cdot 1 \\
46 \cdot 9 \\
47 \cdot 3 \\
50 \cdot 1 \\
48 \cdot 7 \\
49 \cdot 4 \\
49 \cdot 7 \\
49 \cdot 5 \\
48 \\
49 \cdot 5 \\
50 \cdot 5 \\
50 \\
49 \cdot 7 \\
47 \cdot 3 \\
49 \cdot 5 \\
48 \\
48 \cdot 4 \\
47 \cdot 6 \\
46 \cdot 6 \\
47 \cdot 4 \\
47 \cdot 3 \\
47 \\
49 \cdot 5 \\
48 \\
47 \cdot 4 \\
47 \cdot 5 \\
47 \cdot 6 \\
47 \cdot 9\end{array}$ & $\begin{array}{l}45 \\
45 \\
45 \\
45 \\
45 \\
45 \\
45 \\
45 \\
45 \\
45 \\
45 \\
45 \\
45 \\
45 \\
45 \\
45 \\
45 \\
45 \\
45 \\
45 \\
45 \\
45 \\
45 \\
45 \\
45 \\
45 \\
45 \\
45 \\
45\end{array}$ & $\begin{array}{r}42 \\
11 \\
34 \\
36 \\
31 \\
32 \\
26 \\
11 \\
19 \\
21 \\
24 \\
12 \\
24 \\
24 \\
18 \\
18 \\
18 \\
18 \\
8 \\
12 \\
15 \\
18 \\
16 \\
12 \\
10 \\
12 \\
12 \\
12 \\
12\end{array}$ \\
\hline $\begin{array}{l}40 \\
41 \\
42 \\
43 \\
44\end{array}$ & $\begin{array}{l}106 \\
150 \\
158 \\
290 \\
136\end{array}$ & $\begin{array}{l}26 \\
52 \\
39 \\
94 \\
33\end{array}$ & $\begin{array}{l}39 \\
43 \\
48 \\
46 \\
50\end{array}$ & $\begin{array}{l}54 \\
45 \\
89 \\
61 \\
70\end{array}$ & $\begin{array}{l}47 \\
48 \cdot 2 \\
48 \\
49 \\
47\end{array}$ & $\begin{array}{l}45 \\
45 \\
45 \\
45 \\
45\end{array}$ & $\begin{array}{r}9 \\
8 \\
11 \\
9 \\
6\end{array}$ \\
\hline
\end{tabular}

with silicone adhesive (Dow Corning Corp, Midland, MI, USA). Though temperatures were constantly monitored within the microwave field by means of an optically isolated computer controlled TM-12 thermometry system (Physitemp, Clifton, NJ, USA), after patient 10 the treatment temperatures were determined when the field had been turned off for 2 seconds. This was called microwave 'field-off' technique. This technique minimised the effect of the microwave field on the metallic thermocouples and thereby reduced the possibility of temperature artefact.

\section{Microwave treatment}

All patients in this series received one microwave thermotherapy treatment. Surgical implantation of the episcleral radioactive plaques was performed by standard and ring transillumination tumour localised techniques. ${ }^{27}$ Small, posteriorly located tumours were often localised by scleral depression. During transillumination the edges of the tumour were marked on the sclera with tissue dye. Then a hand held cautery was used to mark episclera. These marks were used for placement of the microwave antenna at the time of radioactive plaque removal. Microwave applicators were chosen such that the diameter of the copper portion of the antenna would equal or (more commonly) exceed the tumour's basal diameter by $1-2 \mathrm{~mm}$. The active surface of the microwave antenna was pressed against the sclera beaneath the choroidal tumour. Unlike radioactive plaque therapy, microwave thermotherapy required firm contact between the active surface of the plaque and the sclera. Thermotherapy was performed for 45 minutes. The first 10 patients were treated as high as $52 \cdot 2^{\circ} \mathrm{C}$ (as measured within the microwave field). Since that time all patients were treated to 'field-off' episcleral temperatures in a range of $47-50^{\circ} \mathrm{C}$ (Table 2 ). Since we know that our microwave applicators lose on average $1^{\circ} \mathrm{C}$ per axial millimetre into the eye and/or tumour, episcleral temperatures were selected so as to target the tumour's apex to a minimum of $42^{\circ} \mathrm{C}$. This assumption was based on experiments performed with our applicators in rabbit eyes and phantom materials. ${ }^{19-2128}$ Similar intraocular heat distributions have been reported by Reidel et $a l^{29}$ and Swift $e t a l^{30}$ using equivalent or ringtype microwave applicators.

RADIATION TREATMENT

Standard COMS-type gold plaques (Trachsel Dental Studio Inc, Rochester, MN, USA) were used in most cases. Radioactive I-125 seeds were available (3M Corp, St Paul, MN, USA) at strengths ranging from 0.5 to $40 \mathrm{mCi} / \mathrm{seed}$, and palladium-103 seeds were available (Theragenics Corp, Norcross, GA, USA) at strengths of up to $2 \mathrm{mCi} /$ seed. Each seed's strength was checked in a well counter prior to plaque assembly.

Dosimetric calculations were performed in a manner similar to the COMS protocol, in which a number of assumptions were required. All the seeds were calculated as point sources (no correction for anisotrophy). No attenuation 
effect was attributed to the side walls of the gold plaque, the silastic seed carrier, or acrylic used to hold the seeds within the plaque. ${ }^{31}$ The radiation enhancing effect of 'back scatter' from the posterior wall of the gold plaque was discounted. ${ }^{32}$ Lastly, the US National Cancer Institute (NCI) Brachytherapy Contract Group suggests that the dose rate constant for I- 125 may be up to $19 \%$ lower than their measured values. ${ }^{33}$ To make our findings comparable with the results from our experience and the clinical standard at most centres, this study incorporates the same approximate dose inflation factor of $19 \%$. Our calculations used the specific dose rate constants of $(1.32 \mathrm{cGy} / \mathrm{h} / \mathrm{mCi})$ for $\mathrm{I}-125$ and $(1.09 \mathrm{cGy} / \mathrm{h} /$ $\mathrm{mCi})$ for $\mathrm{Pd}-103$, which were standardised at $1 \mathrm{~cm}$ in water. ${ }^{3+39}$

All patients in this series received one radiotherapy treatment. Radioactive plaque (I-125, Pd-103) brachytherapy started at insertion and continued until the prescribed dose was delivered to the tumour's apex (Table 2). Though 44 patients with choroidal melanoma have been treated, there are three treatment groups.

The first group of 10 patients were treated with I-125 plaque radiation and microwave thermotherapy (during or after radiotherapy). Temperatures were measured within the microwave field and are therefore not comparable to subsequent patients' thermal doses. Their mean apex radiation dose (minimum tumour dose) was $65 \mathrm{~Gy}$, and their mean follow-up has been 39 months (Table 2).

The second group, the largest and the most notable set of 29 patients, were treated with a combination of I-125 plaque radiotherapy followed by microwave thermotherapy. Temperatures were determined with 'field-off' technique. Their mean apex radiation dose was $53 \mathrm{~Gy}$, and their mean follow-up has been 19 months (Table 2). A relatively uniform method and thermoradiotherapy dose were used for this group.

The third group of patients (five patients) were treated with the same relatively uniform thermoradiotherapy method and dose as group 2 , except that Pd-103 seeds were used instead of I-125 for plaque radiotherapy. Thermotherapy temperatures were determined by 'field-off' technique. The mean apex radiation dose was 45 Gy, and their mean follow-up has been 9 months (Table 2). Though the type of radiation emitted from Pd-103 seeds was the same as from I-125 owing to greater absorption in tissue the normal ocular structures were calculated to receive significantly less radiation with $\mathrm{Pd}-103$ than with I-125..$^{39-41}$

\section{Results}

We report on the first clinical trial of microwave thermotherapy for the treatment of choroidal melanoma. This was a non-randomised phase-I clinical trial, from which evolved a technique for adjuvant microwave thermotherapy for treatment of intraocular tumours. In that most heatrelated side effects are likely to occur during or immediately after treatment, all microwave treated eyes (treatment groups) were significant.

There have been three side effects which could

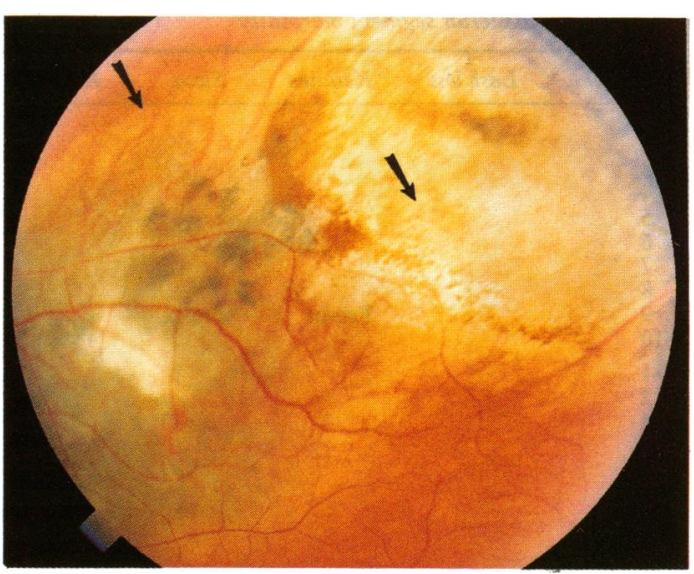

Figure 2 An area of chorioretinal attenuation is noted around and anterior to the tumour's base in a patient 10 months after being treated with $55 \mathrm{~Gy}$ (apex) $48^{\circ} \mathrm{C} \times 45 \mathrm{~min}$ thermoradiotherapy (arrows).

be attributed to microwave thermotherapy. The first and most important has been chorioretinal attenuation within and anterior to the treatment zone (Fig 2). No evidence of scleral damage has been noted on either ophthalmoscopy or ultrasonography. This reaction has been noted in a total of 13 patients ( 12 of whom were treated with 'field-off' technique). The second side effect may be related to this chorioretinal reaction. Eyes with tumours anterior to the equator or involving the ciliary body were noted to have persistently decreased intraocular pressure (without hypotony). The third side effect was a relatively non-progressive anterior subcapsular cataract noted in patient 17 immediately after surgery (Table 3A).

In 44 patients there has been one possible failure of local control (defined as documented tumour growth greater than $15 \%$ in apical height). Patient 32's tumour was $10 \times 10 \times 6.4$; after 18 months his tumour has grown to $7 \cdot 4 \mathrm{~mm}$, while its basal dimension has remained unchanged. This tumour was treated to a basal radiation dose of $292 \mathrm{~Gy}$, an apical radiation dose of $55 \mathrm{~Gy}$, and is being followed-up for further documentation of growth.

There have been two enucleations, one in patient $\mathbf{1 0}$ for glaucomatous complications of a bilateral uveitis 39 months after treatment, the second in patient 19 for rubeotic glaucoma 19 months after treatment. Ten patients have developed some form of secondary retinopathy (Table 3B). Three had pre-existing diabetes and developed an asymmetric diabetic like nonproliferative retinopathy. Patient 19 had a total exudative 'tumour-dissolution' retinopathy ${ }^{42}$ leading to the rubeotic glaucoma, and two have developed radiation retinopathy (one with an associated optic neuropathy). Two have developed rings of exudate round their tumours, and two have developed subretinal neovascularisation within the treatment zone. Argon laser photocoagulation has been used to treat the two cases of subretinal neovascularisation (SRN), and panretinal photocoagulation has been used in the one case of radiation retinopathy with optic neuropathy. There have been two cases of perioperative subretinal tumour haemorrhage (Table 3B). Both occurred in patients with pre- 
Table 3A Anterior segment morbidity

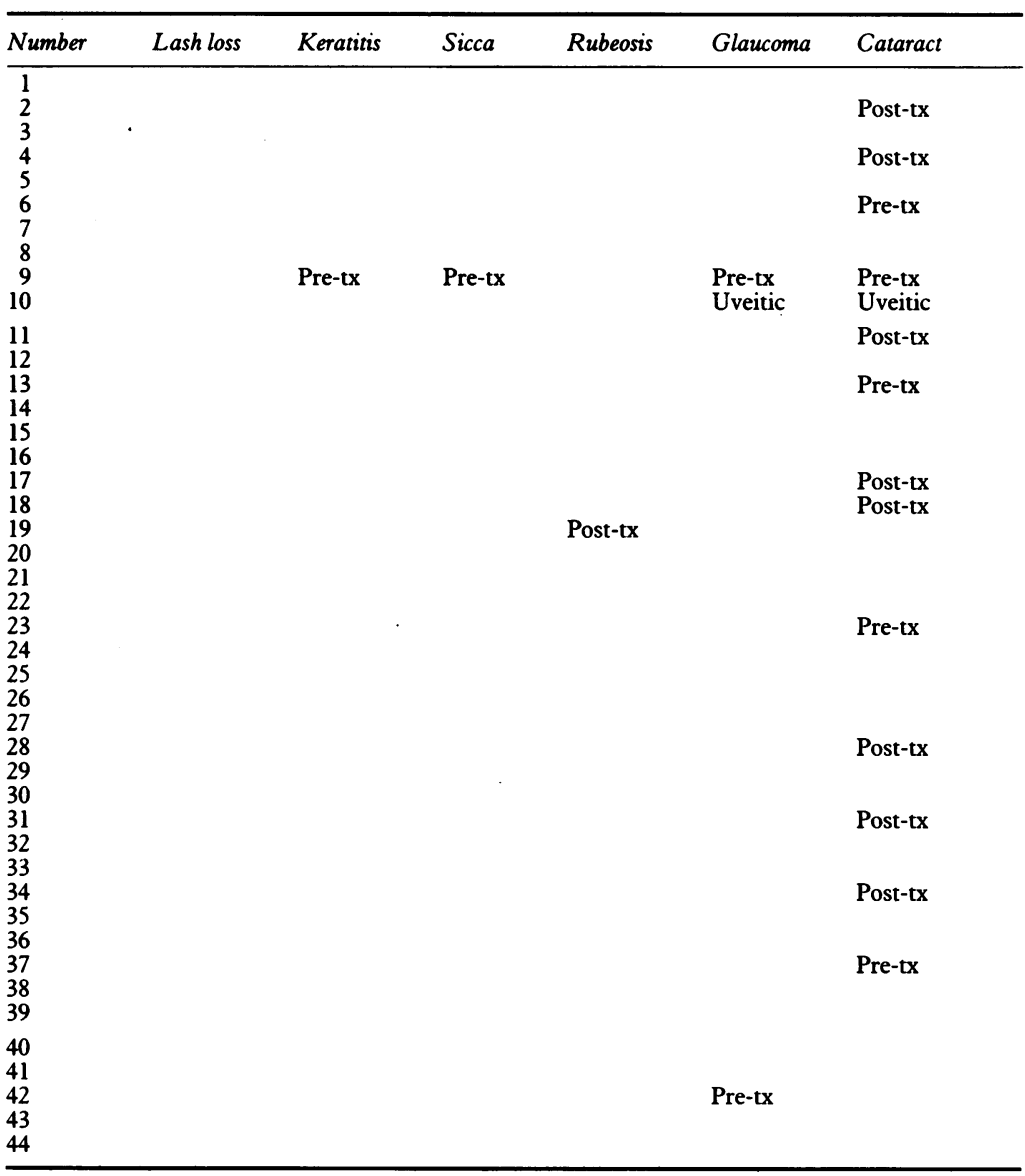

existing diabetes, and in one (patient 18) blood dissected to the macula and caused persistent decreased vision (Table 4).

Patterns of visual acuity change were largely dependent on pre-existing ocular conditions: the proximity of the tumour to the fovea, the presence of retinal (foveal) detachment, vitreous haemorrhage, cataract, and cystoid macular oedema. Postoperative patterns were largely dependent on the resolution of foveal detachments, vitreous haemorrhages, the development of cataract (radiation and non-radiation induced), the appearance of radiation maculopathy, and/or cystoid macular oedema. At this follow-up interval 13 patients have lost two or more lines of vision (including the two patients whose eyes were enucleated). Among the 11 remaining patients who experienced serious visual loss, the condition in two was primarily caused by persistent retinal detachments through their foveas, in two it was due to treatment-associated cataract formation, in two due to natural progression of pre-existing cataracts, in two due to increased diabetic retinopathy, in one to perioperative subretinal haemorrhages with secondary macular damage, in one to an exacerbation of a pre-existent cystoid macular oedema, and in one to internal limiting membrane wrinkling through his fovea. Five patients are currently experiencing improvement of two or more lines in visual acuity. Four were secondary to resolved foveal detachments, and one has been due to resolution of his cystoid macular oedema (Table 4).

Table 3B Posterior segment morbidity

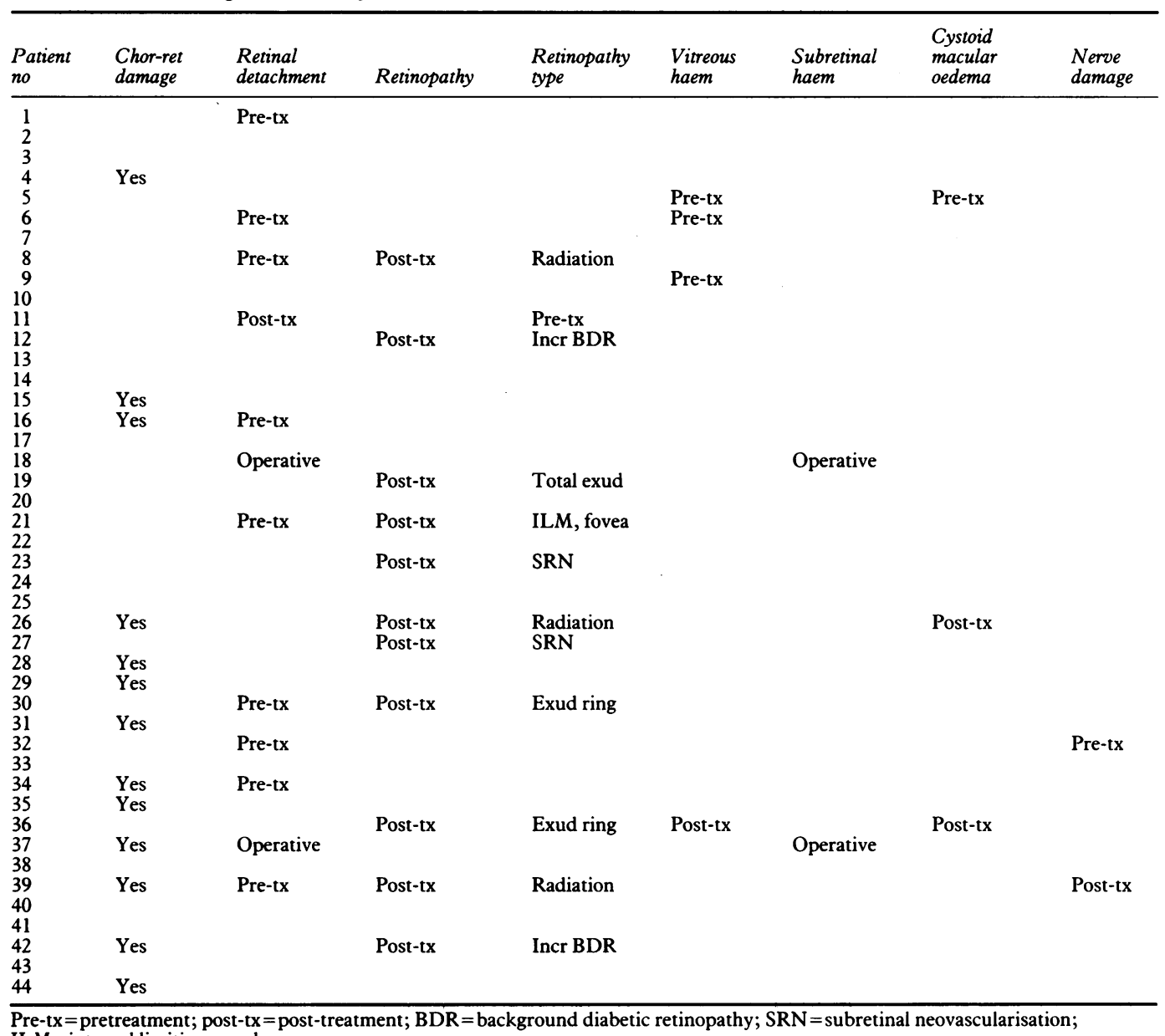


Table 4 Results

\begin{tabular}{|c|c|c|c|c|c|c|c|}
\hline Number & $\begin{array}{l}\text { Apex height } \\
\text { pre-tx }\end{array}$ & $\begin{array}{l}\text { Apex height } \\
\text { most recent }\end{array}$ & $\begin{array}{l}\text { Vision } \\
\text { pre-tx }\end{array}$ & $\begin{array}{l}\text { Vision most } \\
\text { recent }\end{array}$ & $\begin{array}{l}\text { Vision change } \\
\text { primary cause }\end{array}$ & $\begin{array}{l}F / U \\
\text { months }\end{array}$ & Death \\
\hline $\begin{array}{r}1 \\
2 \\
3 \\
4 \\
5 \\
6 \\
7 \\
8 \\
9 \\
10\end{array}$ & $\begin{array}{c}3 \\
3 \\
3 \cdot 5 \\
12 \cdot 2 \\
4 \\
10 \\
3 \\
4 \cdot 7 \\
3 \cdot 7 \\
8 \cdot 4\end{array}$ & $\begin{array}{l}2.9 \\
0.9 \\
1.4 \\
8.4 \\
1.9 \\
7.6 \\
1.8 \\
2.9 \\
1.7 \\
4.7\end{array}$ & $\begin{array}{l}20 / 40 \\
20 / 25 \\
20 / 20 \\
20 / 200 \\
20 / 200 \\
\mathrm{HM} \\
20 / 60 \\
20 / 200 \\
20 / 200 \\
20 / 40\end{array}$ & $\begin{array}{l}20 / 25 \\
20 / 30 \\
20 / 15 \\
20 / 200 \\
20 / 50 \\
\text { FC } \\
20 / 60 \\
20 / 200 \\
20 / 200 \\
\text { NLP }\end{array}$ & Enucleation & $\begin{array}{l}12 \\
52 \\
48 \\
55 \\
48 \\
29 \\
21 \\
36 \\
44 \\
46\end{array}$ & $\begin{array}{l}\text { MI } \\
\text { MI }\end{array}$ \\
\hline $\begin{array}{l}11 \\
12 \\
13 \\
14 \\
15 \\
16 \\
17 \\
18 \\
19 \\
20 \\
21 \\
22 \\
23 \\
24 \\
25 \\
26 \\
27 \\
28 \\
29 \\
30 \\
31 \\
32 \\
33 \\
34 \\
35 \\
36 \\
37 \\
38 \\
39\end{array}$ & 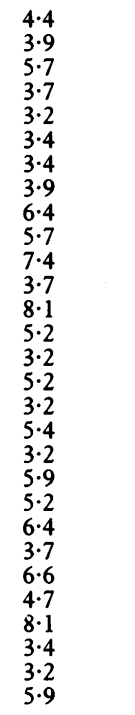 & 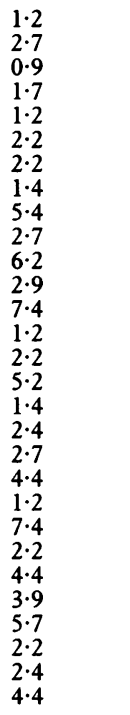 & $\begin{array}{l}\text { HM } \\
20 / 20 \\
\text { HM } \\
20 / 30 \\
20 / 25 \\
20 / 50 \\
20 / 15 \\
20 / 25 \\
20 / 200 \\
20 / 30 \\
20 / 20 \\
20 / 20 \\
20 / 40 \\
20 / 40 \\
20 / 200 \\
20 / 40 \\
\mathrm{FC} \\
20 / 25 \\
20 / 400 \\
20 / 70 \\
20 / 30 \\
20 / 40 \\
20 / 20 \\
20 / 60 \\
\mathrm{FC} \\
20 / 30 \\
20 / 40 \\
20 / 30 \\
20 / 400\end{array}$ & $\begin{array}{l}\text { HM } \\
20 / 40 \\
\text { LP } \\
20 / 20 \\
20 / 30 \\
20 / 25 \\
20 / 30 \\
20 / 200 \\
\text { NLP } \\
20 / 40 \\
20 / 30 \\
20 / 20 \\
20 / 60 \\
20 / 50 \\
20 / 200 \\
20 / 30 \\
\text { FC } \\
20 / 20 \\
\text { FC } \\
20 / 200 \\
20 / 30 \\
\text { FC } \\
20 / 20 \\
\text { FC } \\
20 / 400 \\
\text { FC } \\
20 / 50 \\
20 / 50 \\
20 / 30\end{array}$ & $\begin{array}{l}\text { Incr BDR } \\
\text { Unknown } \\
\text { Decr SRF } \\
\text { Heat cataract } \\
\text { Sub ret haem } \\
\text { Enucleation } \\
\text { ILM foveopathy } \\
\text { Non-RT cataract }\end{array}$ & $\begin{array}{l}42 \\
11 \\
34 \\
36^{\star} \\
31 \\
32 \\
26 \\
11 \\
19 \\
21 \\
24 \\
12 \\
24 \\
24 \\
18 \\
18 \\
18 \\
18 \\
8 \\
12 \\
15 \\
18 \\
18 \\
12 \\
10 \\
12 \\
12 \\
12 \\
12\end{array}$ & $\begin{array}{l}\text { Sepsis } \\
\text { Melanon }\end{array}$ \\
\hline $\begin{array}{l}40 \\
41 \\
42 \\
43 \\
44\end{array}$ & $\begin{array}{l}3 \cdot 4 \\
5.9 \\
4 \cdot 2 \\
8.6 \\
3 \cdot 4\end{array}$ & $\begin{array}{l}2 \cdot 9 \\
5 \cdot 2 \\
4 \cdot 2 \\
5 \cdot 9 \\
2 \cdot 2\end{array}$ & $\begin{array}{l}20 / 20 \\
20 / 100 \\
20 / 30 \\
20 / 40 \\
20 / 20\end{array}$ & $\begin{array}{l}20 / 25 \\
20 / 40 \\
20 / 200 \\
20 / 40 \\
20 / 20\end{array}$ & $\begin{array}{l}\text { Decr SRF } \\
\text { Incr BDR }\end{array}$ & $\begin{array}{r}9 \\
8 \\
11 \\
9 \\
6\end{array}$ & \\
\hline
\end{tabular}

* Metastasis; $\mathrm{CME}=$ cystoid macular oedema; $\mathrm{MI}=$ myocardial infarction;

$\mathrm{PSRF}=$ persistent subretinal fluid; $\mathrm{RT}=$ radiation therapy; $\mathrm{SRF}=$ subretinal fluid.

As measured by ultrasonography, microwave thermoradiotherapy caused a greater than 0.3 $\mathrm{mm}$ reduction in apical tumour height in 40 patients, less than a $0.3 \mathrm{~mm}$ decrease or no change in three patients. An increased apical tumour height (greater than 15\% increase in tumour height) in one patient for a $\mathbf{9 7 \cdot 7 \%}$ local control rate (Table 4).

Six patients have died: three of heart disease, one of sepsis, one of metastatic prostate cancer, and one patient of metastatic choroidal melanoma (39 months after treatment) (Table 4).

\section{Discussion}

In the treatment of choroidal melanoma radiotherapy has been used to stop tumour growth or achieve shrinkage in over $90 \%$ of cases. $^{41+3-49}$ After treatment 30 to $40 \%$ of eyes have experienced significant radiation-associated ocular complications. ${ }^{49-55}$ The incidence and location of complications were related to the method of radiation delivery, the size of the tumour (therefore the amount of radiation delivered to the eye), the location of the tumour, and its response to radiotherapy.

In plaque treatment a radioactive device was sutured to the sclera beneath the intraocular tumour. Radiation then travelled through and was absorbed by the eye wall, the tumour, the vitreous, and by normal ocular structures. To decrease radiation-associated complications one must lower the dose to normal ocular structures without compromising local tumour control. We have used an adjuvant therapy, namely microwave thermotherapy, to reduce the minimum tumour dose (apex dose) to levels used for thermoradiotherapy of cutaneous melanomas. By reducing the amount of radiation delivered to the tumour apex to approximately $50 \mathrm{~Gy}$ (5000 rad tumour apex dose) the amount of radiation delivered to normal ocular structures has been decreased by $50 \%$ or more in comparison with most centres. ${ }^{24}$

Because hyperthermia has been shown to make radiation therapy more effective, a number of methods to produce hyperthermic treatment of intraocular tumours are being investigated. ${ }^{19-21263056-63}$ A comparison of the physics and energy deposition characteristic of each heat delivery system as it relates to ocular hyperthermia is not within the scope of this paper. Microwave heat delivery systems appear to be the most commonly used forms of hyperthermic treatment of cancer. ${ }^{6+}$ This is because microwave cables are easily incorporated into implanted brachytherapy catheters, and deep tissue heating can be induced with surface applicators. The antennas described in this series were both implanted and required to induce heat at depth from the sclera.

In a non-randomised phase I clinical trial the ophthalmic microwave plaques described were employed to deliver adjuvant thermotherapy to 44 choroidal melanomas. The results of this study indicate that microwave plaque thermotherapy can be performed as an adjuvant to radiotherapy of choroidal melanoma. In comparison with published reports on complications after radiotherapy of choroidal melanoma there have been no new complications which might preclude the use of this system of adjuvant microwave plaque thermotherapy..$^{19-55}$

$1 \mathrm{Kim}$ JH, Hahn EW, Ahmed SA. Combination hyperthermia and radiation therapy for malignant melanoma. Cancer 1982 50: $478-82$.

2 Manning MR, Cetas TC, Miller RC, Oleson JR, Conner WG, Gerner EW. Clinical hyperthermia: results of a phase I trial employing hyperthermia alone or in combination with external beam or interstitial radiotherapy. Cancer 1982; 49: 205-16.

3 Molls M, Scherer E. The combination of hyperthermia and radiation: clinical investigations. Recent Results Cancer Res 1987; 104: 110-35.

4 Emami B, Perez CA, Leybovich L, Straube W, Vongerichten D. Interstitial thermoradiotherapy in the treatment malignant tumours. Int $\mathcal{F}$ Hyperthermia 1987; 3: 107-18.

5 Linares LL, Nori D, Brenner H, Sheiu M, Ballon D, Anderson LL, et al. Interstitial hyperthermia and brachytherapy: a preliminary report. Endocurietherapy Hypertherm

6 Meyer JL. The clinical efficacy of localized hyperthermia. Cancer Res 1984; 44 (suppl 10): 4745s-51s.

7 Overgaard K, Overgaard J. Hyperthermic tumor-cell devitalization in vivo. Acta Radiol 1977; 16: 1-16.

8 Song CW, Kang MS, Rhee JG, Levitt SH. The effect of hyperthermia on vascular function, $\mathrm{pH}$, and cell survival. Radiology 1980; 137: 795-803.

9 Dikomey E. Effect of hyperthermia 42 and 45 degrees centigrade on repair of radiation-induced DNA strand breaks in CHO cells. Int $\mathcal{F}$ Radiat Oncol Biol Phys 1982; 41 : 603-14.

10 Bicher HI, Hetzel FW, Sandhu TS, Frina KS, Vaupel P, O'Hara MD, et al. Effects of hyperthermia on normal and tumor microenvironment. Radiology 1980; 137: 523-30.

11 Reinhold HS, Endrich B. Invited review: tumor microcirculation as a target for hyperthermia. Int $f$ Hypermicrocirculation as a target

12 Streffer C, van Beuningen D. The biological basis for tumor therapy by hyperthermia and radiation. Recent Results therapy by hyperthermia and
Cancer Res 1987; 104: 24-70.

13 Dewey WC, Hopwood LE, Sapareto SA, Gerweck LE Cellular responses to combinations of hyperthermia and radiation. Radiology 1977; 123: 463-74. 
14 Song CW. Effect of local hyperthermia on blood flow and microenvironment. A review. Cancer Res 1984; 44 (suppl): $4721 \mathrm{~s}-30 \mathrm{~s}$

15 Dudar TE, Jain RK. Differential response of normal and tumor microcirculation to hyperthermia. Cancer Res 1984; 44: 605-12.

16 Hofer KG, Mivechi NF. Tumor cell sensitivity to hyperthermia as a function of extracellular and intracellular $\mathrm{pH}$. $\mathcal{J}$ Nat Cancer Inst 1980; 65: 621-5.

$17 \mathrm{Kim}$ SH, Kim JH, Hahn EW. The radiosensitization of hypoxic tumor cells by hyperthermia. Radiology 1975; 114 $727-8$.

18 Vaupel P, Kallinowski F. Physiologic effect of hyperthermia. Recent Results Cancer Res $1987 ; 104: 71-109$.

19 Finger PT, Packer S, Svitra PP, Paglione RW, Anderson LL, $\mathrm{Kim} \mathrm{JH}$, et al. Thermoradiotherapy for intraocular tumors. Arch Ophthalmol 1985; 103: 1574-8.

20 Finger PT, Packer S, Sivitra PP, Paglione RW. A 5.8 GH ophthalmic microwave applicator for treatment of choroida melanoma. IEEE MTT-S International Microwave Symposium Digest 1983; F-1: 177-179 (83 CH 1871-3).

21 Finger PT, Packer S, Svitra PP, Paglione RW, Chess J, Albert DM. Hyperthermic treatment of intraocular tumors. Arch Ophthalmol 1984; 102: 1477-81.

22 Finger PT, Curtin BJ, Packer S, Svitra PP, Iwamoto T, Whitmore WG, et al. Scleral hyperplasia induced by heat Am 7 Ophthalmol 1986; 102: 25-32.

23 Goldblatt WS, Finger PT, Perry HD, Stroh EM, Weiser DS Donnenfeld ED. Hyperthermic treatment of rabbit corneas. Invest Ophthalmol Vis Sci 1989; 30: 1778-83.

24 Earle J, Kline RW, Robertson DM. Selection of iodine-125 for the collaborative ocular melanoma study. Arch Ophthalmol 1987; 105: 763-4.

25 Green RL, Byrne SF. Diagnostic ophthalmic ultrasound. In Ryan SJ, ed. Retina. St Louis: Mosby, 1989; 2: chapter 17: Ryan SJ,
$191-273$.

26 Finger PT, Packer S, Paglione RW, Gatz JF, Ho TK Bosworth JL. Thermoradiotherapy of choroidal melanoma

27 Percuoco VA, Finger PT, Svitra PP. A ring transilluminator for ophthalmic plaque radiotherapy. Invest Ophthalmol Vis Sci 1991; 32 (suppl): 1195 .

28 Grabczyk J, Finger PT, Fetter RW. A thermochromatic gel block system developed to illustrate heating patterns produced by ophthalmic microwave applicators. Invest Ophthalmol Vis Sci 1989; 30 (suppl) 9.

29 Reidel KG, Plischke H, Turkner KH, Russer P. Thermoradiotherapy of choroidal melanoma: new compact 2.45 $\mathrm{GHz}$ microstrip applicators Invest Ophthalmol Vis Sci 1991; 32 (suppl): 1196

30 Swift PS, Stauffer PR, Fries PD, Kaleta-Michaels S, Murray T, Sneed PK, et al. Microwave hyperthermia of choroidal melanoma in rabbits. Invest Ophthalmol Vis Sci 1990; 31: melanoma

31 Chiu-Tsao ST, Anderson LL, Stabile L. TLD dosimetry for I125 plaque. (abstract). World Congress on Medical Physics and Biomedical Engineering, San Antonio, Texas, 1988: 128 .

32 Luxton G, Astràhan MA, Petrovich Z. Backscatter measurements from a single seed of I-125 for ophthalmic plaque dosimetry. Med Phys 1988; 15: 397-400.

33 Weaver KA, Smith V, Huang D, Barnett C, Schell MC, Ling C. Dose parameters of I-125 and $\mathrm{Ir}-192$ seed sources. Med Phys 1989; 16: 636-43.

34 Ling CC, Schell MC, Yorke ED, Palos BB, Kubiatowicz DO. Two-dimensional dose distribution of I-125 seeds. Med Phys 1985; 12: 652-5.

35 Ling CC, Yorke ED, Spiro IJ, Kubiatowicz D, Bennet D Physical dosimetry of I-125 seeds of a new design for interstitial implant. Int $\mathcal{F}$ Radiat Oncol Biol Phys 1983; 9 : $1747-52$.

36 Anderson LL, Kwan HM, Ding IY. Clinical dosimetry with I125. In: George FW, ed. Modern interstitial and intracavitary radiation in cancer management. New York: Masson, 1981: 9 15 (Cancer management: V.6)

37 Chiu-Tsao ST, Anderson LL. Thermoluminescent dosimetry for Pd-103 seeds (Model 200) in a solid water phantom. Med Phys 1991; 18: 449-52.

38 Meigooni AS, Sabnis S, Nath R. Dosimetry of palladium-103 brachytherapy source for permanent implants. Endocurietherapy Hypertherm Oncol 1990; 6: 107-17.

39 Finger PT, Ho TK. Palladium-103 plaque radiotherapy for choroidal melanoma. Invest Ophthalmol Vis Sci 1991; 32 (suppl): 979.
40 Ho TK, Finger PT, Moshfeghi DM. In vitro dosimetry comparing palladium-103 vs. iodine- 125 for ophthalmic plaque radiotherapy. Invest Ophthalmol Vis Sci 1991; 32 (suppl): 1195

1 Finger PT, Moshfeghi DM, Ho TK. Palladium-103 ophthalmic plaque radiation therapy. Arch Ophthalmol 1991; 109: 1610-13.

42 Char DH, Castro JR, Quivey JM, Phillips TL, Irvine AR, Stone RD, et al. Uveal melanoma radiation. I-125 brachytherapy versus helium-ion irradiation. Ophthalmology 1989; 96: 1708-15.

43 Stallard HB. Malignant melanoblastoma of the choroid. Bibl Ophthalmol 1968; 75: 16-38.

44 Stallard HB. Radiotherapy for malignant melanoma of the choroid. Brf Ophthalmol 1966; 50: 147-55.

45 Lommatzsch PK. Treatment of choroidal melanomas with ${ }^{106} \mathrm{Ru} /{ }^{100} \mathrm{Rh}$ beta-ray applicators. Surv Ophthalmol 1974; 19: $85-100$.

46 Sealy R, Buret E, Cleminshaw H, et al. Progress in the use of iodine therapy for tumors of the eye. Br $\mathcal{F}$ Radiol 1980; 53: $1052-60$

47 Packer S, Rotman M. Radiotherapy of choroidal melanoma with iodine-125. Ophthalmology 1980; 87: 582-90.

48 Bosworth JL, Packer S, Rotman M, Ho TK, Finger PT. Choroidal melanoma I-125 plaque therapy. Radiology 1988; 169: 249-51.

49 Gragoudas ES, Goiten M, Verhey L, Munzenreider J, Urie M, Suit $M$, et al. Proton beam irradiation of uveal melanoma: results of 51/2 year study. Arch Ophthalmol 1982; 100: 928 34.

50 Shields JA, Augsburger JJ, Brady LW, Day JL. Cobalt plaque therapy of posterior uveal melanomas. Ophthalmology 1982; 89: $1201-7$.

51 Kim MK, Char DH, Castro JL, Saunders WM, Chen GTY, Stone RD. Neovascular glaucoma after helium-ion irradiation for uveal melanoma. Ophthalmology 1986; 93: 189-93.

52 Davidorf RH, Makley TA, Lang JR. Radiotherapy of malignant melanoma of the choroid. Trans Am Acad Ophthalmol Otolaryngol 1976; 81: 849-61.

53 Lommatzsch PK. Beta-irradiation of choroidal melanomas with ${ }^{106} \mathrm{Ru} / 106 \mathrm{Rh}$ applicators: 16 years experience. Arch Ophthalmol 1983; 101: 713-7.

54 Foerster MH, Bornfeld N, Shulz U, Wessing A, MeyerSchwickerath G. Complications of local beta radiation of uveal melanomas. Graefes Arch Clin Exp Ophthalmol 1986; 224: 336-40.

55 Packer S, Rotman M, Salanitro P. Iodine-125 irradiation of choroidal melanoma: clinical experience. Ophthalmology 1984; 91: 1700-8.

56 Lagendijk JJ. A microwave heating technique for the hyperthermic treatment of tumours in the eye, especially retinoblastoma. Phys Med Biol 1982; 27: 131324.

57 Reidel KG, Svitra PP, Seddon JM, Albert DM, Gragoudas ES, Koehler AM, et al. Proton beam irradiation and hyperthermia: effect on experimental choroidal melanoma. Arch Ophthalmol 1985; 103: 1862-9.

58 Coleman DJ, Lizzi FL, Burgess SE, Silverman RH, Smith $\mathrm{ME}$, Driller J, et al. Ultrasonic hyperthermia and radiation in the management of intraocular malignant melanoma. Am f Ophthalmol 1986; 101: 635-42.

59 Reidel KG. Hypertherme Therapieverfahren in Erganzung zur Strahlenbehandlung maligner intraokularer Tumoren. Klin Monatsbl Augenheilkd 1988; 2: 131-7.

60 Astrahan M, Ligget P, Petrovich Z, Luxton G. A $500 \mathrm{KHz}$ localised current field hyperthermia system for use with ophthalmic plaque therapy. Int $\mathcal{f}$ Hyperthermia 1987; 3: 42332 .

61 Finger PT, Paglione RW, Packer S. Microwave thermotherapy for choroidal hemangioma. Am $\mathcal{F}$ Ophthalmol 1991; 111: $240-1$.

62 Braakman $R$, van der Valk $P$, van Delft JL, de WolffRouendaal D, Oosterhuis JA. The effects of ultrasonically induced hyperthermia on experimental tumors in the rabbit eye. Invest Ophthalmol Vis Sci 1989; 30: 83544.

63 Mieler WF, Jaffe GJ, Steeves RA. Ferromagnetic hyperthermia and iodine-125 brachytherapy in the treatment of choroidal melanoma in a rabbit model. Arch Ophthalmol 1989; 107: 1524-8.

64 Hand JW. Heat delivery and thermometry in clinical hyperthermia. Recent Results Cancer Res 1987; 104: 1-23. 